УДК (1+91)477

\begin{abstract}
БАЗАЛУК О. А., доктор философских наук, профессор, Заслуженный работник образования Украины, профессор кафедры философии Переяслав-Хмельницкого государственного педагогического университета имени Григория Сковороды (Переяслав-Хмельницкий, Украина)E-mail bazaluk@ukr.net
\end{abstract}

\title{
ГЕОФИЛОСОФИЯ УКРАИНЫ
}

Предметом исследования автора является геофилософия Украины. По мнению автора, чтобы понять истинные причины событий, которые произочли и происходят в Украине на протяжении всей её истории, нужно понять особенности геофилософии этого региона. Автор считает, что основная особенность геофилософии этого региона, которая и формирует ментальность украинцев уже многие столетия, заключается в том, что территориально современная Украина расположена на стыке двух мощнейших культур Евроазиатского континента: азиатской и европейской. Автор предложил свое видение формирование рубежности культур и их влияния на становление украинской нации. $B$ статье использованы диалектический метод, системно-структурный, структурнофункииональный, а также методы: сравнения, анализа и синтеза. Основнылм вкладом автора в исследование этой актуальной и сложной темы является очередная попытка объективного исследования историко-культурных связей между Москвой и Киевом, россиянами и украиниами. Новизна исследования - показать Украину и украинцев изнутри, во всей их противоречивости и стремлении установить собственные культурные маркеры самоидентификации.

Ключевые слова: геофилософия, Украина, Россия, Москва, Киев, европейская культура, азиатская культура, Киевская Русь, Великое Московское княжество, империя

\section{Понятийный и методологический аппарат исследования}

Впервые понятие «геофилософия» встречается в работе Жиль Делёза и Феликса Гваттари «Что такое философия?», вышедшей во Франции в 1991 году. У них геофилософия - это «пространственная модель имманентной философии, основанной на соотнесении территории и земли» $[1$, с. 85]. В дальнейшем, понимание геофилософии значительно углубили и расширили Николо Масиандаро [2], Бэн Вудэрд [3], Тейлор Вэб и Калерво Галсон [4] и другие. Однако автор понимает геофилософию шире. Если смотреть на геофилософию не как на понятие, введенное в научный оборот только в конце $\mathrm{XX}$ столетия, а как на философию географии, то сложность и важность проблем, поднимаемых геофилософией сравнима с онтологией, гносеологией и другими определяющими философскими дисциплинами. Первые исследования по философии географии встречаются у Древних греков и, на самом деле, геофилософия Делёза и Гваттари - это только видимая часть исследований,

(C) Базалук О.А., 2016 
корни которых уходят в апофатическое миропостижение. Масштабный анализ философии географии проведен украинским философом Юлианом Тютюнником [5]. Тютюнник обосновывает апофатику-основание геофилософии из учений Алексея Лосева, Мартина Хайдеггера и Жиль Делёза. Например, у Лосева: «Сущность начинается с апофатического момента. Сущность насыщена смыслом и бытием, из её недр бьет неистощимый ключ её жизни и всё новых и новых определений» [6, с. 150]. У Хайдеггера: «Это непостижимое встречается нам только тогда, когда мы продумываем положение об основании словно бы в обратном направлении, не в направлении поля и сферы его применения, а в направлении его собственного происхождения, т. е. того, исходя откуда говорит само положение» $[7$, с. 107]. У Делёза: «Когда мы говорим, что тела и их смеси производят смысл, то это происходит $<\ldots>$ не благодаря индивидуализации, которая уже предполагала бы наличие смысла. <..> Смысл производится телами неким иным способом. Речь <..> идет о телах, взятых в их недифференцированной глубине и беспорядочной пульсации. Глубина действует здесь необычным образом: посредством своей способности организовывать поверхности и сворачиваться внутри поверхностей. <..> Поверхность ни активна, ни пассивна, она продукт действий и страданий перемешанных тел» [8, с. 155-156]. Таким образом, геофилософия раскрывает смыслы поверхности Земли, смыслы её ландшафтов, составной частью которых является, в том числе и человек.

Геофилософия рассматривает Землю и цивилизации, которые её заселяют и как «поверхность» и, одновременно, как «поверхность», которая образована глубиной, которая имеет свои корни - «ризому». Тютюнник определяет предмет географии - локус (locus), а саму географию, как науку о бесконечности локализации [5, с. 55]. В своем исследовании мы используем геофилософию исключительно в применении к человеческой цивилизации, поэтому и предмет исследования геофилософии в нашем понимании значительно сужается. Он сводится до исследования локусов цивилизаций, которые имеют свою глубину, свою историю, ризому. Однако в связи с тем, что ризома - это сложно переплетенное корневище, которое в глубине, часто имеет единое основание, а к поверхности, разветвляется (или наоборот, в глубине разные основания, которые к поверхности переплетаются в единое и прочное основание), локусы цивилизаций предстают не в разорванном виде, а как относительно целостная поверхность, местами «перекраиваемая», конфликтующая, а местами гладкая и цельная. Поэтому предмет исследования геофилософии, в нашем понимании, это локусы цивилизаций (культур), а объект исследования геофилософии - поверхность Земли, сотканная из локусов разрозненных цивилизаций (культур); цельная поверхность цивилизации Земли, склонная к бесконечности локализации.

Методология геофилософии, как точно отметил Юлиан Тютюнник, сопрягает науку и философию [5, с. 159]. Это позволяет рассматривать поверхность непрерывно изменяющихся локусов цивилизаций Земли, как целостное пространство; определять стыки (границы) локусов, а также 
углубляться в смыслы локусов цивилизаций, высвечивая их глубину. Для этих целей геофилософия задействует доступные методы из политической философии, морфологии культуры (культурологии), этнологии, экономики и географии. Благодаря разносторонности методов, своей междисциплинарности, геофилософия в состоянии выполнить три основные задачи:

1. Исследовать непрерывно изменяющуюся поверхность «сотканных» воедино локусов разрозненных цивилизаций (мировых культур), т.е. рассматривать бесконечную локализацию земной цивилизации в прошлом, настоящем и будущем.

2. Изучать отдельные локусы цивилизаций, высвечивая их глубину, распутывая корневища, докапываясь до основания, истоков отдельно взятой культуры. Это позволяет установить прочность поверхности локуса и его устойчивость в отношении к близлежащим локусам цивилизации, а также к непрерывному процессу перекраивания границ поверхности земной цивилизации.

3. Изучать стыки (соединения, границы) разрозненных локусов цивилизации, определять крепость соединения и вероятность разрыва. Когда в дальнейшем мы будем говорить об уровне рубежной энергетики на стыке мировых культур, то мы подразумеваем крепость связи между разрозненными локусами цивилизации. Чем ниже рубежная энергетика, тем прочнее связь между разрозненными локусами, тем «глаже поверхность» в этом месте и слабее проявляются границы. Чем выше рубежная энергетика - тем сильнее нагрузка на стык, вероятней разрыв и перекраивание границ локусов.

\section{Стыки локусов цивилизаций}

Логика нашего исследования построена на том, что территория Украины расположена на стыке двух крупных, устойчивых локусов цивилизации. В научной литературе стыки (границы) локусов разрозненных цивилизаций обозначают понятием лимитроф (от поздне-латинского limitrophus «граничащий с»). Учение о лимитрофах, как искусственных границах (в нашей терминологии - стыках между разрозненными локусами цивилизаций) c середины XIX столетия активно разрабатывалось школой немецкой геополитики: Фридрихом Ратцелем, Рудольфом Челленом, Фридрихом Науманом и другими. В конце XIX столетия лорд Джордж Керзон ввел в научный оборот понятие «буферное государство», под которым понимал буферные образования на стыках более мощных государств [9]. В первой половине XX столетия немецкий мыслитель Карл Шмитт предложил концепцию «Большого пространства» (Großraum), которая в его понимании призвана заменить понятие «территория» как классического понятия национального государства, понятием «пространство», с его подвижными и заранее неопределенными границами [10]. Во второй половине XX столетия фундаментальный труд Кеннета Боулдинга вывел исследование лимитрофов на новый уровень понимания. Рассматривая понятия «сфера жизненных 
интересов» и «сфера влияния», Боулдинг ввел в научный оборот понятие «критические границы» [11].

Таким образом, лимитроф в нашем понимании - это территория, которая географически пролегает вдоль крупных разрозненных локусов цивилизации. Эта территория проходит через так называемые пограничные государства, которые входят в «сферу влияния» и «сферу жизненных интересов» противостоящих крупных локусов. Например, если мы взглянем на Рис. 1, то увидим, что лимитрофными государствами, которые расположены вдоль границы двух крупных устойчивых локусов: Российской Федерации и Европы, являются Украина, Беларусь, Латвия и Эстония.

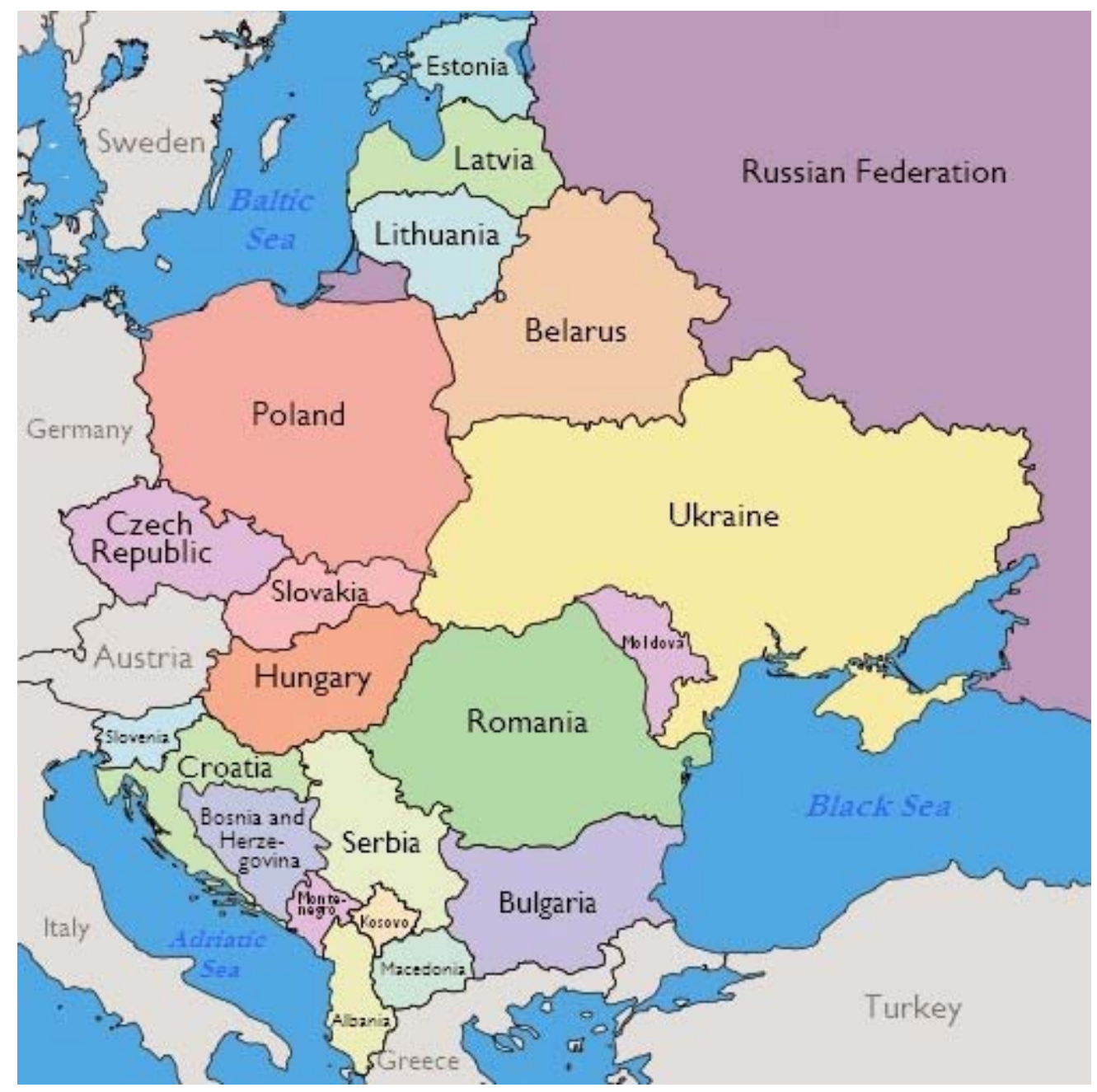

Рис. 1. Карта Восточной Европы, 2015 год.

\section{На переломе двух культур. Основы геофилософии Украины}

Чтобы понять истинные причины событий, которые произошли и происходят в Украине на протяжении всей её истории, нужно понять особенности геофилософии этого региона. Основная особенность геофилософии Украины, которая и формирует ментальность украинцев уже многие столетия, заключается в том, что территориально современная Украина 
расположена на стыке двух мощнейших культур Евроазиатского континента: азиатской и европейской. Такая сложная и ответственная участь постигла Украину в начале XIII столетия. В 1237-1240 годах войска Монгольской империи в ходе Западного похода монголов (Кипчакского похода) под предводительством чингизида Батыя и военачальника Субэдэя захватили территории уже распавшегося к тому времени в результате феодальной раздробленности Древнерусского государства со столицей в Киеве. Таким образом, уже с XIII столетия на территории восточной Европы стало формироваться коммуникационное пространство с высокой рубежной энергетикой, своеобразный стык европейской и азиатской культуры. Более 250лет монгольской оккупации привело к тому, что на территории заселенной восточными славянами родились поколения, в ментальности которых доминировали азиатские ценности, такие как:

- уважительное и почтенное отношение к старшим;

- вера в сильную власть и централизованное государство;

- уважительное отношение к своим традициям и культуре;

- доминирование интересов общины над личными потребностями и интересами;

- услужливость, безропотность и почитание власти;

- минимализм и аскетизм в быту и личных потребностях, и др.

Для новых поколений восточных славян вошли в практику набеги на собратьев: южных и западных славян, а также совместные княжеско-ордынские походы на Литву, Польшу и Венгрию. С каждым поколением оккупированные монголами восточные славяне все сильнее отличались от западных и южных славян, германцев, кельтов, балтов и финно-угорских народов, чьи потомки заложили основу европейской культуры.

Начиная с XIV столетия, благодаря поддержке Орды, ранее окраинное княжество Древнерусского государства Московское княжество, стало набирать силу и многократно расширило свою территорию за счёт соседних русских княжеств. Началось «собирание русских земель» вокруг новых политических центров. В Северо-Восточной Руси этот процесс возглавило Великое княжество Московское, находящееся в союзе с монголами и под их влиянием. В ЮгоЗападной Руси собиранием русских земель занималось Великое княжество Литовское, также не брезговавшее союзами с татарами.

B XIV столетии в результате внутренних противоречий могущество Монгольской империи значительно ослабло. Это позволило Великому княжеству Литовскому отвоевывать земли, ранее принадлежавшие Древнерусскому государству, тем самым отодвинуть границы азиатской культуры на восток. В Северо-Восточной Руси монголо-татарское иго продлилось дольше, до 1480 года.

Древнерусское государство как политическая организация больше не возродилось. Город Киев, столицу Древнерусского государства (по разным источникам Киев возник в VI-VII столетии), в 1240 году монголы разграбили и разрушили практически до основания. С 1362 года по 1569 год Киев входит в

(C) Базалук О.А., 2016 
состав Великого княжества Литовского, а с 1569 года по 1654 год - в состав Речи Посполитой. В 1654 году в городе происходит антипольское и антилитовское восстание и Киев переходит «под руку московского царя». Однако вплоть до середины XVIII века Киев (польск. Kijów) испытывал значительное влияние польской культуры. С 1654 года по 1991 год Киев находился под влиянием Москвы. По состоянию на 2015 год в Киеве проживает чуть менее 2,9 млн. человек. Это седьмой по величине город в Европе.

В формате Московского княжества (1263-1547), Русского царства (15471721), Российской Империи (1721-1917), СССР (1917-1991) и Российской Федерации (с 1991 года), самобытная культура Древнерусского государства присутствовала уже в значительно меньшей степени. Почти двести пятьдесят лет монгольского ига сыграли свою роль в формировании и развитии ментальности древнерусского этноса. Теперь в нем присутствовали атрибуты азиатской культуры и традиций, которые в разные периоды истории в большей или меньшей степени отличались от европейской культуры. В начале $\mathrm{XX}$ столетия авторитетный русский философ Николай Бердяев провел глубокое исследование отличия азиатской и европейской души русских. Полемизируя с Максимом Горьким, который в статье «Две Души» взывал к русскому народу: «Нам нужно бороться с азиатскими наслоениями в нашей психике, нам нужно лечиться» [12, с.180], Николай Бердяев писал: «Поистине в русской душе есть «азиатские наслоения» и они очень всегда чувствуются в радикальном западничестве горьковского типа» [13, с.127].

Не все русские стыдились азиатских наслоений в своей культуре. Например, Николай Трубецкой, автор концепции культурно-исторических регионов, считал, что основная задача России создать исключительно свою культуру, отличающуюся от европейской. В книге «Наследие Чингисхана», вышедшей в 1925 году, Трубецкой утверждает, что Россия-Евразия является сознательной наследницей и носительницей великого наследия Чингисхана и русский народ связан с евразийскими народами общностью исторической судьбы. Николай Трубецкой отрицает значимость и жизнеспособность Древнерусского государства в деле построения России. В его понимании Российская Империя и СССР являются геополитическим продолжением монгольской монархии, основанной великим Чингисханом [14].

Таким образом, даже после освобождения от монгольского ига, территория современной Украины продолжала оставаться водоразделом между экспансией азиатско-европейской культуры Московского княжества и носителем европейской культуры Великим княжеством Литовским. Впоследствии это противостояние приобрело более масштабные формы: более 800 столетий по территории современной Украины пролегает цивилизационный раскол между православной и западной цивилизацией в терминологии Самюэля Хантингтона [15].

Я хочу уточнить терминологию, а именно обозначение культуры Московского княжества, правопреемниками которого выступили: Русское царство, Российская Империя, СССР и, наконец, Российская Федерация. В 
западном научном дискурсе культуру Московского княжества, достигшего максимальных границ при СССР, в разное время обозначали по-разному. Например, в начале XX столетия Освальд Шпенглер назвал её «русскосибирской» мировой культурой [16; 17]. Несколько позже Арнольд Тойнби назвал её «русская цивилизация» [18]. В конце XX столетия Самюэль Хантингтон назвал её «православной цивилизацией», значительно расширив её границы [15]. Ни один из этих терминов в самой русской культуре не прижился, потому что не отражает ни её амбиций, ни действительного положения вещей.

На самом деле, культура Московского княжества, дошедшая до наших дней, состоит из различных культурных наслоений, которые действительно дают право говорить о ней как о самодостаточной евразийской культуре. В порядке первоочередности в ней можно выделить следующие культурные слои:

1. Византийская культура, правопреемником которой, начиная с царствования Ивана III (1440-1505) Русское царство себя назначило. В связи с упадком Киева как политического центра (после разгрома монголами в 1240 году) в конце 1325 года местопребыванием Киевских митрополитов стала Москва. Именно здесь, по мере роста могущества Московского княжества выдумали легенду, согласно которой, вследствие духовного и политического падения Византии, единственным оплотом вселенского православия становится Москва, получившая достоинство Третьего Рима. Начиная с XV столетия и до наших дней, установка: Москва - Третий Рим, является определяющей для понимания культуры России и имперских амбиций московских правителей.

2. Азиатская культура. Под азиатской культурой я понимаю, прежде всего, многокультурие Монгольской империи эпохи Чингисхана. Для становления Московского княжества значение азиатской культуры не менее важно, чем византийской культуры. Именно благодаря вторжению Монгольской империи на русские земли, а потом дружбе (и поддержке!) с ханами Орды, заурядное русское княжество получило шанс покорить более могущественные княжества Древнерусского государства и расширить сферу своего влияния. Не зря в XVI столетии, уже после распада Золотой Орды, московские историки добавили к Орде возвеличивающее прилагательное «Золотая». До 1566 года на Руси во всех источниках татар называли просто «Ордой». Дружба с татарами стала действительно «золотой» эпохой для Московского княжества.

Говоря об «азиатских наслоениях» в русской культуре, Николай Бердяев предостерегал: «...не следует смешивать темного, дикого, хаотического азиатского Востока с древней культурой азиатского Востока, представляющего самобытный духовный тип, привлекающий внимание самых культурных европейцев. На Востоке - колыбель всех великих религий и культур» [13, c.127]. Поэтому и мы в своем исследовании, когда говорим об «азиатщине» или проявлениях азиатской культуры на постсоветском пространстве, подразумеваем не богатейшую культуру азиатского Востока, которая сыграла важнейшую роль в становлении многих мировых культур, включая и культуру

(C) Базалук О.А., 2016 
на землях Киевской Руси (об этом аргументировано писал Лев Гумилев [19]), а её побочные негативные проявления, крайности. Например, церемониальность, помпезность, официальность, надменность, раболепие, чинопочитание и чинопоклонение, а также взяточничество, любовь к роскоши, барству и многое другое.

3. Европейская культура, или в терминологии Самюэля Хантингтона западная цивилизация. Влияние европейской культуры на евразийскую культуру Московского княжества и его правопреемников значительно уступает влиянию византийской и азиатской культуры. Однако сами россияне всегда с оговорками признаются в этом влиянии, при этом напрочь отрицая зависимость своей культуры (не забываем, что именно Москва - Третий Рим!) от западной. Большая часть истории от Московского княжества до Российской Федерации это внутреннее неприятие (вплоть до изоляции) европейской культуры или конкуренция с нею за право доминирования в западной части Евразийского континента.

4. Культура Древнерусского государства. В самодостаточной евразийской культуре Российской империи культура Древнерусского государства присутствует. Однако мы должны учитывать важнейший исторический факт: в Древнерусском государстве со столицей в Киеве, Московское княжество было окраинным княжеством, расположенном на расстоянии более 800 километров от столицы, что для XI столетия составляло огромное расстояние! Для Киева эпохи Древнерусского государства Москва слыла глухой провинцией. Именно поэтому понимание наследия культуры Древнерусского государства Москвой и Киевом всегда разительно отличалось. Выражаясь современной терминологией, Москва в культуре Русов чтила консерватизм, обряды и атрибутику, а Киев перенимал дух свободы, величие мысли и открытость к новаторству и изменениям. Именно поэтому, как не парадоксально это звучит, украинцы больше русские, чем россияне, потому что для украинцев история Древнерусского государства - это история Киевской Руси, а для россиян история Древнерусского государства - это московское восприятие и оценка событий в Киевской Руси.

Западные исследователи не понимают важнейшего несходства между Киевом и Москвой, украинцами и русскими, которое всегда отличало, отличает и будет отличать этот на первый взгляд единый народ и культуру. Совершенно не важно, как мы называем культуру Великого Московского княжества, правопреемником которого является Российская Федерация: или «русскосибирской» мировой культурой [16; 17], или «православной цивилизацией» [15]. Важно то, что в этой культуре украинцы не видят своего места. Киев, как древний и богатейший культурный центр с определенной территорией влияния и украинский народ, как хранитель и носитель этой культуры, претендует (и небезосновательно!) на роль не придатка к чей-то культуре, тем более к культуре ранее воссального Московского княжества, а к возрождению самостоятельного локуса. С XIII столетия украинцы пытаются воссоединиться в былых границах и обрести независимость. За восемь столетий попытки 
возрождения русской государственности (в понимании Киева!) происходили неоднократно. Например, а) вторая треть XII - 40-е годы XIV столетия, этап существования Галицко-Волынского государства (или иначе, Русского королевства, на латыне Regnum Russiæ), унаследовавшего традиции Киевской Руси; б) 1340 - последняя четверть XV столетия, украинские земли вошли в состав Великого княжества Литовского, которое в новейших исторических исследованиях именуется как Литовско-Русское государство. 9/10 населения Литовско-Русского государства составляли украинцы и белорусы; в) с 1648 по 1764 года, существование Запорожской сечи (Украинское гетманское государство); г) с 1917 по 1921 год - период украинского национальноосвободительного движения; д) наконец, с 1990 года по настоящее время, существование независимой Украины. Все эти этапы становления украинской государственности опирались на историю Киевской, а не Московской Руси. Для украинцев история Киевской Руси является непререкаемой святыней и неиссякаемым источником борьбы за независимость.

В отличие от Украины и украинцев, которые только пытаются восстановить свою государственность, Московское княжество сумело написать свою, не менее, а возможно даже, и более великую историю, чем была у Древнерусского государства. Вопрос только в деталях, датах первородности культуры, которые значимы, но не до такой степени. Пусть Московское княжество с большой натяжкой может претендовать на роль Третьего Рима и носителя культуры Киевской Руси, зато вся последующая его история по величию и значимости действительно сопоставима с историей Древнерусского государства, Римской и Монгольской Империи. История Московского княжества - это история великого народа, который смог создать свою собственную, неповторимую, самодостаточную евразийскую культуру, завоевать и длительное время удерживать территорию, сопоставимую (и даже превосходящую!) с территориями Римской и Монгольской империями. С вершин этой культуры, из Москвы, Киев теперь воспринимается как окраина, глухая провинция с завышенной самооценкой, «...бедный родственник, вечно стоящий с протянутой рукой» - слова экс-президента Российской Федерации, премьер-министра Российской Федерации Дмитрия Медведева, написанные им в аккаунте Facebook 2 марта 2014 года.

На мой взгляд, культуру Российской Федерации корректнее называть византийско-азиатской культурой, что подчеркивает её действительную значимость, величие и имперские амбиции. Хотя еще раз подчеркиваю, совершенно не важно, как называется та или иная культура (локус), в том числе и культура, представленная Российской Федерации. Важно то, что в этой культуре Украина, со своим неиссякаемым стремлением возродить величие культуры Киевской Руси, доказать свою историческую значимость - это чужеродный организм, патология, с которой Москва то мирится, то пытается удалить. Если к этому добавить другой, не менее важный фактор, а именно, что территория современной Украины частично состоит из территорий, которые ей никогда раньше не принадлежали (например, Крым, Галиция, Волынь,

(C) Базалук О.А., 2016 
Полесье), а достались только по велению правителей Москвы, то становится понятным полное неприятие Украины как независимого государства правителями Российской Федерации.

За последние несколько столетий в результате постоянных войн и территориальных споров византийско-азиатская культура значительно потеснила европейскую культуру, прижала её к берегам Атлантического океана. Основной представитель византийско-азиатской культуры в Европе Россия, в формате СССР и стран Варшавского блока, во второй половине XX столетия смогла продвинуть влияние византийско-азиатской культуры вглубь Европы, и навязать конкуренцию европейской культуре в самом её центре: у границ Франции и располовинчатой Германии. То, что в XIII столетии не удалось сделать в результате монгольского нашествия, сделал Советский Союз на Ялтинской (Крымской) конференции союзных держав 4-11 февраля 1945 года. Установленный так называемый послевоенный мировой порядок означал проникновение византийско-азиатской культуры в центральную Европу.

Ялтинская конференция союзных держав 1945 года, а также создание Организации Варшавского договора в мае 1955 года на некоторое время снизило цивилизационное давление на территорию Украины. Высокая рубежная энергетика, связанная с противостоянием византийско-азиатской и европейской культуры, сместилась на страны Балтии, Польши, Румынии и Чехословакии. Воссоединенная Украина отошла вглубь византийско-азиатской культуры и получила на несколько десятилетий возможность передохнуть и восстановить свой потенциал. Однако в 1991 году после распада СССР и Варшавского договора, граница между двумя цивилизациями вновь вернулась в исходное положение, и пролегла по территории Украины. Каждый год независимости Украины - это рубежное противостояние культуры Востока и Запада, это перетягивание Украины то под Москву, то к европейскому выбору.

\section{Украина как самостоятельный локус цивилизации}

Таким образом, Украина является не только лимитрофным государством, но и государством, претендующим на роль самостоятельного локуса цивилизации. На стыке византийско-азиатской и европейской цивилизации в 1991 году (после распада СССР) сложилась довольно уникальная ситуация образовалось не просто «буферное государство», в терминологии лорда Джорджа Керзона [9], находящееся в сфере влияния двух крупных локусов, а сформировался самостоятельный локус, имеющий тысячелетнюю историю, огромную по масштабам Европы территорию и численность населения. Особенность и сложность этого локуса заключалась в том, что примерно $55 \%$ населения ментально склонялась к «сфере влияния» и «сфере жизненных интересов» византийско-азиатского локуса цивилизации, но при этом занимала всего 1/3 часть территории локуса, а $45 \%$ населения, которое занимало $2 / 3$ территории ментально склонялось к «сфере влияния» и «сфере жизненных интересов» локуса европейской (западной) цивилизации (Рис. 2). 


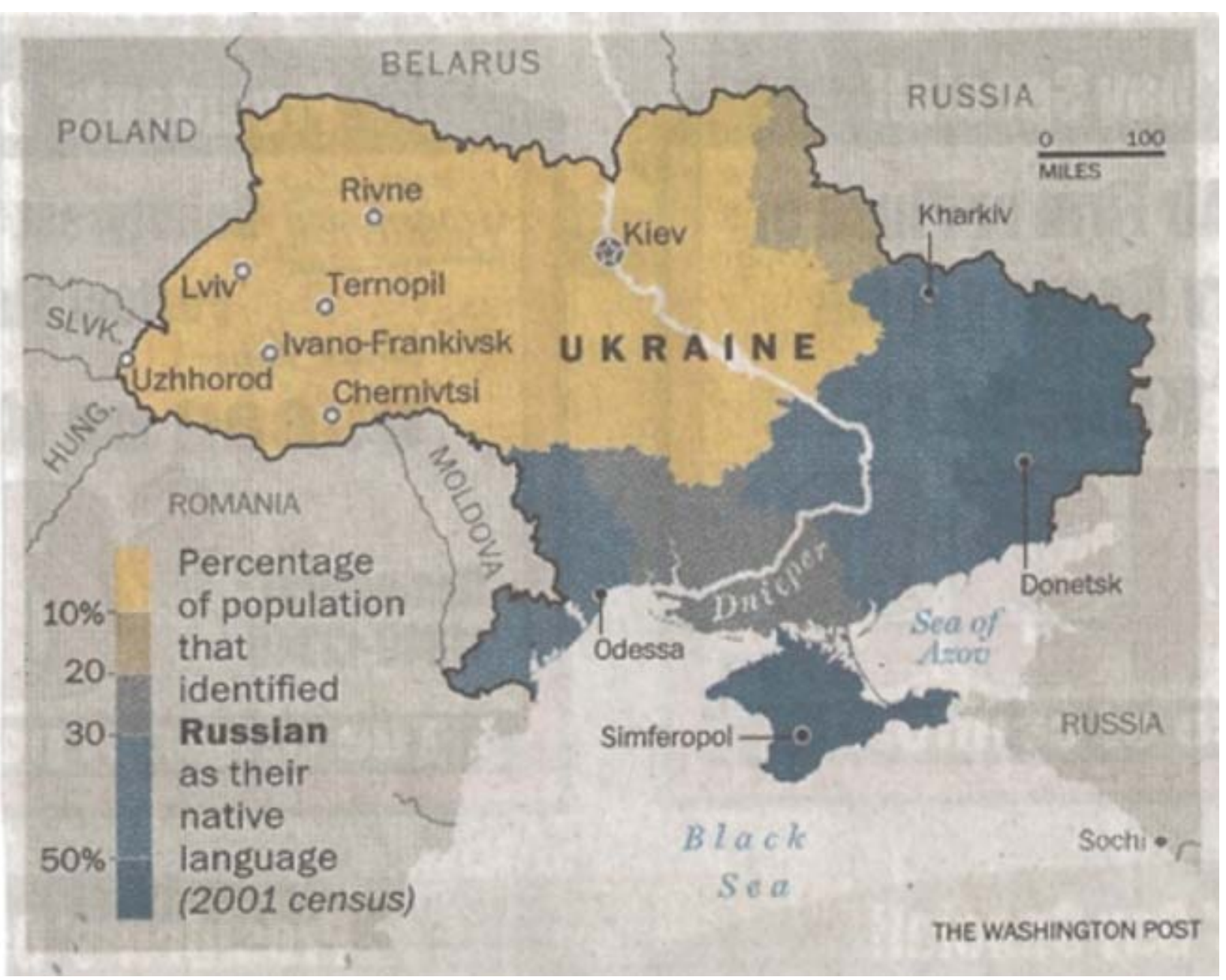

Рис. 2. Карта соотношения русскоговорящего (серый цвет) и украинско-говорящего населения Украины, 2001 год.

Но что еще более интересней, этот локус цивилизации возникает на этом участке поверхности Земли уже не первый раз, что указывает на его устойчивость в глубинных слоях поверхности, в корневище. Последнее его появление произошло в период украинского национально-освободительного движения с 1917 по 1921 год, и осмысливалось в целом ряде работ. Например, Михаила Грушевского, Ярослава Дашкевича, Дмытра Донцова, Вячеслава Липинского, Ивана Лысяка-Рудницкого и др. История локуса украинской цивилизации исследована в фундаментальных работах Богдана Гаврилишина, Мыколы Рябчука, Наталии Яковенко, Валерия Смолия и многих других.

Проявившийся в 1990 году на поверхности цивилизации Земли локус украинской цивилизации, несмотря на глубину и устойчивость своей ризомы, у поверхности противоречив и склонен к дальнейшей локализации на более мелкие локусы. Ему не хватает национальной идеи, маркеров культурной идентификации, чтобы скрепить поверхность, состояться как целостному локусу цивилизации. 


\section{Украинская национальная идея}

Методология геофилософии дает нам возможность абстрагироваться от деталей и выделить в истории украинской государственности основоопределяющее предназначение украинского народа в мировой культуре. Еще с XIII столетия ход развития евразийских цивилизаций сложился так, что территорией Украины пролег рубеж между двумя мировыми культурами: азиатской, впоследствии принявшей форму византийско-азиатской, и европейской культуры. Украина стала окраиной как одной, так и другой культуры, откуда, как предполагает историк Наталья Яковенко, и возникло её название [20]. История формирования украинской государственности - это история влияния трех культур: юго-восточная Украина формировалась под доминирующим влиянием византийско-азиатской культуры (которая представлена восточным соседом - Российской Федерацией); западная Украина, под влиянием ценностей европейской культуры (главным образом, через влияние со стороны Польши и Румынии); а вот центральная Украина со столицей в Киеве хранила в себе первородную культуру Древнерусского государства, культурные маркеры, позволяющие идентифицировать украинский этнос как самостоятельный и значимый для истории цивилизации. Причем значимость украинского этноса для мировой цивилизации, особенно для евразийской истории, к сожалению, не понимается до сих пор. Украина и украинцы продолжают восприниматься чужаками, как в российской, так и европейской истории. Однако иначе и быть не может, потому что Украина и украинцы - это пограничье двух культур со своей самобытной сердцевиной! Восемь столетий (с небольшими перерывами) по территории Украины проходил водораздел двух мировых культур, а украинцы как нация впитывали в свою древнерусскую сущность элементы византийско-азиатской и европейской культуры. Поэтому украинцев нельзя идентифицировать ни как россиян, ни как европейцев. Украинцы впитали в себя элементы обоих культур, но в корнях остались русинами - этносом, развивающимся от Русского государства со столицей в Киеве. Основным маркером идентификации украинской нации является тысячелетняя культура древнерусского народа с элементами ассимиляции с византийско-азиатской и европейской культурами.

Стоит отметить, что Русское государство в домонгольский период оккупации, территориально и ментально развивалось в традициях культуры, заложившей основы современной европейской цивилизации. Именно отсюда берет начало украинская национальная идея: Украина - Берегиня, а украиниь хранители мира в западной части Евразийского континента. Потому что от спокойствия на Украине зависит спокойствие на границах двух мировых культур.

Украина в территориальной целостности, и украинцы, населяющие эту территорию, достойны уважения в истории византийско-азиатской и европейской культуры хотя бы за то, что вся история украинской государственности и культура украинского этноса формировалась на рубеже противостояния: в войнах, насилии, рабстве, геноциде, унижениях. Каждая из 
двух противостоящих культур (цивилизаций) старалась переломить украинцев под себя, выжечь воспоминания о корнях, о пращурах. Однако в результате всех этих внешних насильственных преломлений сформировалась нацияхранителей, психологический тип казака, который на войне - лучший воин, в мире - образованный и трудолюбивый муж.

Национальная идея: Украина - Берегиня, украинцы - хранители мира в западной части Евразийского континента, не только идентифицирует украинскую нацию, сплачивает, наделяет ролью, позволяющей занять достойное место среди великих народов и культур мира, но и ко многому обязывает. Именно эта цивилизационная нагрузка, предназначение украинской нации и является её основоопределяющими культурными маркерами.

Итак, первая обязанность-предназначение украинской нации боеспособная, хорошо вооруженная армия. Украина - это как непроходимый рубеж: чем сильнее украинская армия, тем безопаснее на пограничье двух культур. Украина - это крепость, внутри которой располагаются форпосты обеих культур. Украинец - это, прежде всего, воин, который отстаивая свою независимость, оберегает границы византийско-азиатской и европейской культуры. Первый маркер культурной идентификащуии украинской нации воин-хранитель.

Вторая обязанность-предназначение украинской нации - высокая образованность. Из своих корней украинцы отмечались образованностью, поэтому эту традицию важно сохранить и приумножить. Высокая образованность украинцев затрудняет манипуляцию сознанием, снижает эффективность информационных войн, расширяет сферы творческой самореализации. Пограничье украинской нации открывает возможность брать для себя лучшее у каждой из культур, применять это лучшее во благо своей тысячелетней культуре. Нет ничего постыдного в учебе, в перенимании лучшего и передового. В современном мире правят высокие технологии, поэтому нация, развивающаяся на пограничье двух мировых культур должна отличаться новаторством, креативностью и технологичностью своих ресурсов. Второй маркер культурной идентификацуии украинской нацуи образованность.

Третья обязанность-предназначение украинской нации законопослушание и дисциплинированность. Украина обязана иметь модель объективной власти - наиболее эффективную в масштабах мировой цивилизации модель государственного управления. Своими древнерусскими корнями украинцы ближе к европейской культуре. Однако искушения византийско-азиатской культуры, модели субъективной власти и отголоски авторитаризма, негативно влияют на ментальность украинских политиков. Власть, деньги и вседозволенность легко превращает демократа-украинца в гетьмана, атамана, диктатора. Поэтому украинцам крайне необходима модель объективной власти, в основе которой заложена правовая культура, законопослушание, дисциплинированность. Перед Законами Украины все равны: от гражданина до президента. Только в этом случае можно избежать

(C) Базалук О.А., 2016 
искушения «азиатчиной». Третий маркер культурной идентификации украинской нации - законопослушание (дисциплинированность).

Четвертая обязанность-предназначение украинской нации - создать активное гражданское общество. Психологический тип казака и ментальность воина - это внутренняя свобода, которая контролируется и регулируется не временными субъективными ценностными ориентациями очередного лидера или диктатора, а Законами Украины, едиными для всех. Все, что не запрещено законами, то разрешено. Внутренняя свобода - это высокая гражданская активность, понимание важности укрепления Украины как крепости: во внешней политике, экономике, науке, образовании и т.п.. Чем сильнее Украина во всех сферах деятельности, тем спокойнее на пограничье, тем меньше вероятность войны, внешней агрессии, оккупации. Только активное гражданское общество может выстроить крепость и сохранить её силу во времени. В отличие от центральных регионов европейской или византийскоазиатской культур, украинцы не могут позволить себе расслабиться и почивать на лаврах. Особенность пограничья - это постоянная бдительность, внедрение лучшего и передового, готовность отстоять собственную независимость и паритет культур. Расслабленность на пограничье, слабость в политике, экономике, внутри социума - это повод для агрессии, наступления одной из культур. Четвертый маркер культурной идентификациии украинской нации внутренняя свобода (активная жизненная позиция).

Пятая обязанность-предназначение украинской нации - Украина обязана оставаться открытым независимым государством. Когда мы говорим об Украине как крепости, мы ни в коем случае не подразумеваем изоляцию или равноудаленность Украины от одной (или от обеих) культур. Для Украины это равносильно гибели, потере независимости или части территорий. Украина не сможет самостоятельно противостоять одной или тем более двум мировым культурам. Когда мы говорим об Украине как крепости, мы наоборот предполагаем её открытость для проникновения обоих культур, её доступность и несопротивление. Пусть россияне или европейцы заходят в крепость, создают сферы своего влияния. Пусть византийско-азиатская и европейская культура проникают не только на территорию Украины, но взаимопроникают друг в друга - это их выбор, на то они и мировые культуры. Однако важно, чтобы это проникновение и влияние оставалось для Украины поверхностным, дополняющим, идущим во благо развивающейся украинской государственности. Важно, чтобы культурное наследие Киевской Руси, идентифицирующее самостоятельность и независимость украинского этноса в масштабах цивилизации, оставалось для украинцев первостепенным, доминирующим и преобладающим по значимости над любой другой культурой. Древнерусская культура Украины - это основополагающая и определяющая культура, ценности которой для украинцев должны стать незыблемыми, священными и культовыми. Для своей же безопасности, Украина должна обрести уважение к своему социально-духовному наследию и четко прописать маркеры культурной идентификации. Украина - крепость, а 
украинцы - воины-хранители, это и есть стержень украинской нации, лед, по поверхности которого прокатываются волны обеих мировых культур, только укрепляя его, но, не проникая в глубинные структуры. Независимая Украина это пограничье Российской Федерации и Европейского Союза одновременно. Пятый маркер культурной идентификации украинской нации - открытость нациии (гостеприимство).

Именно по этой причине Украина не может быть проросийской или проевропейской. Украина обязана оставаться сама собою - Берегиней, хранительницей мира в западной части евразийского континента. Однако для этого ей необходимо максимум усилий, чтобы через образовательную политику заложить в основы подрастающих поколений национальную идею и основные культурные маркеры украинской идентичности: а) воин-хранитель; б) высокая образованность; в) законопослушание (дисциплинированность); г) внутренняя свобода (активная жизненная позиция); д) открытость нации (гостеприимство). Эти маркеры украинской идентичности позволят возродить казацкий тип психологии, вернут уверенность в себе и самодостаточность, позволяя украинцам выдержать груз ответственности, и справится с рубежной энергетикой непрерывно противостоящих друг другу двух мировых культур.

\section{СПИСОК ИСПОЛЬЗОВАННЫХ ИСТОЧНИКОВ}

1. Deleuze, Gilles, and Félix Guattari. What is Philosophy? Trans. Graham Burchell and Hugh Tomlinson. London: Verso, 1994.

2. Masciandaro, Nicola. Becoming Spice: Commentary as Geophilosophy. Collapse Vol. VI: Geo/Philosophy. January, 2010: 20-56.

3. Woodard, Ben. On an Ungrounded Earth: Towards a New Geophilosophy. New York: Punctum Books, 2013.

4. Webb, P. Taylor, and Kalervo N. Gulson. Policy, Geophilosophy and Education. Sense Publishers, 2015.

5. Тютюнник, Юлиан. Философия географии. Киев: Украина, 2011.

6. Лосев, Алексей. Философия имени. Москва: Изд-во Московского университета, 1990.

7. Хайдеггер, Мартин. Положение об основании. Санкт-Петербург: Алетейя, 1999.

8. Делёз, Жиль. Логика смысла. Москва:Академия, 1995.

9. Curzon, George. The place of India in the Empire. London: J. Murray, 1909.

10. Шмитт, Карл. Государство и политическая форма. Москва: Издательский дом Государственного университета - Высшей школь экономики, 2010.

11. Boulding, Kenneth. Conflict and Defence: A General Theory. New York: Harper and Brothers, 1962.

12. Горький, Максим. Статьи 1905-1916. Санкт-Петербург, 1918: 174-187.

13. Бердяев, Николай. Судьба России. Москва: Советский писатель, 1990: 127-128.

14. Трубеикой, Николай. Наследие Чингисхана. Взгляд на русскую историю не с Запада, а с Востока. Москва: Алгоритм, ЭКСМО, 2012.

15. Huntington, Samuel P. The Clash of Civilizations and the Remaking of World Order. New York, NY: Simon and Schuster, 1996.

16. Шпенглер О. Закат Европь: Очерки морфологии мировой истории. Т. 1. Образ и действительность / Пер. с нем. Н. Ф. Гарелин. - Минск: ООО "Попурри", 1998.

(C) Базалук О.А., 2016 
17. Шпенглер О. Закат Европы: Очерки морфологии мировой истории. Т. 2. Всемирно-исторические перспективы / Пер. с нем. С. Э. Борич. - Минск: ООО "Попурри", 1999.

18. Тойнби, Арнольд. Цивилизачия перед судом истории (Сборник). Москва: «Прогресс» «Культура», 1995.

19. Гумилев, Лев. От Руси до России: Очерки этнической истории. Москва: Рольф, 2001.

20. Яковенко, Наталя. Дзеркала ідентичності. Дослідження з історії уявлень та ідей в Україні XVI- початку ХVIII століття. Київ: Laurus, 2012.

BAZALUK, OLEG - Doctor of Philosophy, Professor, Honored Worker of Education of Ukraine, professor of philosophy, Pereyaslav-Khmelnitsky State Pedagogical university of G. Scovoroda (Pereyaslav-Khmelnitsky, Ukraine)

\section{GEOPHILOSOPHY OF UKRAINE}

To understand the true causes of the events that occurred and are occurring in Ukraine, throughout its history, it is necessary to understand the peculiarities of geophilosophy in the region. The author offered, the main feature of geophilosophy in this region, which forms the Ukrainian mentality for centuries, is that modern Ukraine is geographically located at the crossroads of two powerful cultures of Eurasian continent: Asian and European. D. The author has used the dialectical, system-structural, structural-functional research methods as well as methods of comparison, analysis and synthesis. The main contribution of the author in the study of this actual and complex topic is another attempt to of objective research of historical and cultural connections between Moscow and Kiev, Russians and Ukrainians. The novelty of the study - to show Ukraine and Ukrainians from the inside, with all their contradictions and trying to establish their own cultural markers of identity.

Key words: geofilosofiya, Ukraine, Russia, Moscow, Kiev, European culture, Asian culture, Kievan Rus, the Grand Principality of Moscow, the empire 